\title{
Setting the record wrong: a Sanskrit vision of Mughal conquests
}

\author{
Audrey Truschke* \\ Department of Middle Eastern, South Asian, and African Studies, Columbia University, New York, \\ NY, USA
}

In 1589, Padmasāgara wrote the first Sanskrit account of the Mughal rise to power within a short poem titled Jagadgurukāvya (Poem on the Teacher of the World). The work primarily eulogizes the life of a Jain religious leader named Hiravijaya, but Padmasāgara devotes one-third of the text to detailing the military exploits of Humayun and Akbar. Moreover, Padmasāgara departs significantly from known Indo-Persian historiography and imagines a startlingly innovative storyline for the early days of the Mughal Empire. Through this substantial rewriting, he furthermore consistently depicts the coerced establishment of Mughal rule as engendering the flourishing of Indian cultural and religious traditions. In this article, I provide the first detailed account of Padmasāgara's presentation of the battles of Humayun and Akbar to secure their claims over the subcontinent. I then seek to understand the motivations that fuelled this particular narrative by placing Jagadgurukāvya in the context of Gujarati relations with the Mughal court, Jain religious interests and historical sensibilities in early modern India. In his account of the early Mughal Empire, Padmasāgara crafts a political vision in which history is not constituted by a set of unchangeable facts but rather by a range of potential cultural implications that can be best realized through literature. His ambitious narrative about the recent past has important implications for how we understand early modern Sanskrit historiography and its relationship to Mughal power.

Keywords: Mughal; Sanskrit; early modern; Jain; historical memory

In 1589, Padmasāgara wrote the first known account in Sanskrit of the Mughals' rise to power. He embedded this narrative within a poem titled Jagadgurukāvya (Poem on the Teacher of the World), which primarily eulogizes the life of a Jain religious leader named Hīravijaya. However, Padmasāgara devotes one-third of the text to detailing the military exploits of Humayun and Akbar. Moreover, Padmasāgara departs significantly from known Indo-Persian historiography and imagines a startlingly innovative narrative for the early days of the Mughal Empire. Through this substantial rewriting, he furthermore consistently depicts the coerced establishment of Mughal rule as engendering the flourishing of Indian cultural and religious traditions. This ambitious narrative about the recent past has important implications for how we understand early modern Sanskrit historiography and its relationship to Mughal power. In this article, I provide the first detailed treatment of Padmasāgara's presentation of the battles of Humayun and Akbar to secure their claims over India and explore the position of this literary work within larger intellectual, religious and cultural milieus. In his account of the early Mughal Empire, Padmasāgara crafts a political vision in which history is not constituted by a set of unchangeable facts but rather

\footnotetext{
*Email: audrey.truschke@gmail.com 
by a range of potential social and cultural implications that can be best realized through literature.

Padmasāgara operated within the vibrant and increasingly multicultural intellectual milieu of late sixteenth-century north India. During this period, the subcontinent experienced an explosion of Sanskrit scholarship that claimed to be new and innovative and showed an increased historical awareness. For example, Sheldon Pollock and Yigal Bronner have drawn attention to how Sanskrit intellectuals across genres framed their intellectual production through a fresh mindset when compared with their predecessors. ${ }^{1}$ In addition, north India also witnessed other dynamic, specifically cross-cultural developments that unfolded against the backdrop of growing Mughal dominance and the corresponding spread of Perso-Islamic culture. For example, Rosalind O'Hanlon has outlined how Brahmanical social formations shifted rapidly due to increased communication and lucrative patronage opportunities made available by Mughal institutions. ${ }^{2}$ Certain Jain communities, most notably the Tapā Gaccha to which Padmasāgara belonged, also underwent significant changes during this period as their links with the Mughals brought them onto a world historical stage. ${ }^{3}$

Ascetic and lay members of the Tapā Gaccha wielded considerable political influence from the 1580 s into the early 1600 s and often successfully solicited the Mughal crown for imperial concessions. ${ }^{4}$ In connection with these political affiliations, Jains operated in the royal Mughal court in a variety of capacities, particularly during the $1580 \mathrm{~s}$ and $1590 \mathrm{~s}^{5}$ Tapā Gaccha members acted as religious guides on behalf of the Mughals and helped royal figures perform both Hindu and Jain religious rites. For example, Bhānucandra taught Akbar to recite the Süryasahasranāma (Thousand Names of the Sun) in Sanskrit. ${ }^{6}$ Tapā Gaccha representatives joined with the rival Kharatara Gaccha in bathing a Jain idol to counteract the inauspicious astrological circumstances surrounding the birth of a daughter to Jahangir. ${ }^{7}$ Jains also tutored the royal princes, provided access to Sanskrit texts for translation projects and crafted Sanskrit praise poems for imperial figures. They frequently accompanied the king on trips and participated in Akbar's religious debates. Akbar even engaged with internal sectarian religious hierarchies and promoted Tapā Gaccha leaders to new religious ranks on several occasions. ${ }^{8}$ Within this environment of accelerating intellectual and social conections. Padmasāgara initiated the production of Sanskrit histories about the Mughal Empire.

Padmasāgara composed his Poem on the Teacher of the World as a biography 'in memory of Hīra[vijaya]' in 233 verses. ${ }^{9}$ The text itself provides little background regarding the circumstances of its composition, and Padmasāgara names no motivation for his work beyond 'for the sake of universal success' (sarvasiddhyartham). ${ }^{10}$ Few other elucidating details are available about this author, who worked in western India and to whom several other narrative and philosophical works are also attributed (some dubiously). ${ }^{11}$ Hīravijaya, the main subject of Jagadgurukāvya, is far more well documented and was the leader from 1544 to 1596 of the Tapā Gaccha, a Gujarat-based sect of Śvetāmbara Jainism that was on the ascent during the sixteenth and seventeenth centuries. ${ }^{12}$ Most notably for my purposes, Hīravijaya cultivated extensive ties with the central Mughal court, and Padmasāgara focuses on this aspect of the Tapā Gaccha leader's life in his text.

In the first 40 verses of the work, Padmasāgara describes Hīravijaya's early life and his rise to religious leadership. Padmasāgara returns to Hīravijaya's adult life later in his poem, particularly concentrating on a visit the Tapā Gaccha leader paid to Akbar's court in the 1580s. But first Padmasāgara digresses from the story of his named protagonist for 80 verses in order to explain how Humayun and Akbar came to control much of north and central India through a quick succession of brutal victories. While Padmasāgara presents 
an overall accurate story in that the Mughals did come to power, he alters many details of the early conquests in order to characterize the Mughals as an unchallenged and culturally 'Indian' force. Moreover, he adds a subtle but consistent narrative of how the advent of Mughal control benefited Indian society. This literary rewriting of the past intertwined with attestations to the glories of Mughal rule is what makes Jagadgurukāvya a noteworthy, although hitherto largely unexamined text that offers an intensely political recreation of the past.

By discussing the Mughals, Padmasāgara engages with both the historical and multicultural aspects of his rapidly changing world more directly than most of his contemporaries. In detailing military history in particular, he also pointedly explores the relationship of such trends to the Mughal imperium, a connection that we are still struggling to understand today. ${ }^{13}$ In the second section of this article, I seek to make sense of the motivations that fuelled this particular narrative by placing Jagadgurukāvya in the context of Gujarati relations with the Mughal court and Jain religious interests. In the third and final section, I elaborate on Padmasāgara's relationship to Indian traditions of writing about the past and the implications of his text for better understanding one variety of historical sensibilities in early modern India. However, Jagadgurukāvya has not been translated or extensively studied in modern scholarship, and hence I begin with a close reading of the text, in reference to debates concerning the nature of early modern and premodern 'history' in South Asia.

\section{Padmasāgara's account of the Mughals' rise to power}

Before delving into Padmasāgara's version of Mughal military history, a glance at contemporaneous Persian historiography will help to point up the radical nature of his project. The basic trajectory of the early Mughals is well known from a variety of sources. ${ }^{14}$ Coming from Central Asia, Babur established the Mughal Empire in India in 1526, and his son, Humayun, ascended the throne in 1530. Humayun lost all Mughal holdings in India in 1540 and was exiled by Sher Shah Suri, an Afghan rival. The Sur dynasty ruled from Delhi for 15 years. In 1555, Humayun reclaimed Delhi, but his death a short year later left the newly reestablished kingdom in the hands of his teenage son, Akbar. With the help of advisors and generals, Akbar solidified Mughal control over strategic areas during the 1550s and 1560s and took Gujarat in 1572-1573, which gave the Mughals access to western India's bustling industries. This sequence of events was still alive in Indian historical memory when Padmasāgara wrote his Jagadgurukāvya in 1589, a mere 63 years after the initial establishment of a Mughal presence in Delhi. Nevertheless, Padmasāgara admits none of the setbacks experienced by the early Mughals but instead envisions a smooth, swift triumph that ushered in an Indian cultural renaissance.

Padmasāgara opens by describing the Mughals as an Indian dynasty, even before they enter the subcontinent. In reality, the Mughals claimed ancestry from Chingis Khan, a thirteenth-century Mongol emperor, and Timur, a late fourteenth-century Turkish ruler. For Padmasāgara, the Mughals may have originated in central and western Asia, but that land is included within the geography and culture of India.

In the glorious land of India (bhärata) - where more than twenty-five lands exist that have been graced by incarnations of the best of men such as the great, illustrious Jina and Visnu - the wonderful middle region contains shining palaces, idols, great libraries and is inhabited by worthy people. Here lies a great city called Kabul, near the good land of Khurasan, that is filled with good men and known as the dwelling place of heroes. In Kabul, a hundred thousand 
Mughals, their power unbroken and a terror to demonic Hindus (hindvāsuratrāsakam), feast with great pleasure upon hundreds of delicacies at will. ${ }^{15}$

Thus, the Mughals hail from Kabul, which is itself in the heartland (madhyadeśa) of India and is a home to temples, incarnations and idols. This description is unconventional in comparison to both contemporary Sanskrit and Mughal conceptions of 'India'. Although there were Hindu villages and rest houses in connection with merchants further north than Kabul during this period, Sanskrit authors from Akbar's time generally described Kabul and Khurasan as outside of bhärata and part of a culturally distinct land, often characterized by exotic fruits and horses. ${ }^{16}$ Persianate historians likewise conceived of Kabul and surrounding areas as a homeland that the Mughals left in order to conquer hindīstān, which literally means 'the land of the Indians' in Persian and was by definition a foreign place. ${ }^{17}$ Padmasāgara erases this history of migration by portraying the Mughals as being physically and culturally within India from the beginning.

Although he represents the Mughals as Indian, Padmasāgara nonetheless posits a strong dichotomy between the Mughals and 'demonic Hindus'. Hindū is an originally PersoArabic word that commonly referred to people from a particular area or civilization in early modern usages rather than a religious group. ${ }^{18}$ The term first appeared in Sanskrit in the mid-fourteenth century in a curious title claimed by the Vijayanagara kings: 'Sultan among Hindu Kings' (hindūrāyasuratrāna). ${ }^{19}$ Scholars have persuasively argued that the Vijayanagara rulers invoked this appellation to signal their participation in an Islamicate culture of rulership characterized by particular expressions and behaviours. These refined 'Sultans' stood in contrast to ordinary 'Hindu' kings who drew exclusively from traditional Indic discourses to articulate their authority. ${ }^{20}$ Padmasāgara follows in this tradition of employing hind $\bar{u}$ to indicate a type of kingship outside of Islamicate (in his case, Mughal) norms and, later in his text, specifically narrows 'demonic Hindus' to Rajput rulers in central and western India. ${ }^{21}$

After introducing the Mughals as the preferable Indian alternative to Rajputs, Padmasāgara tells how Humayun set out from Kabul to establish the geographic contours of his empire. He begins with the acquisition of Delhi.

One time, [Humayun] placed the burden of kingship on his eight-year old son Akbar, whose ascension was undisputed, and went to conquer land up to the ocean with an army that was itself an ocean of utter destruction. First he approached the city of Delhi, whose impenetrable borders were lined with soldiers and which was home to wealthy men. ${ }^{22}$

The subsequent verses feature a clash between Humayun and an unnamed 'Sur king'. Padmasāgara describes the battle with meticulous detail, including the numbers of troops, wings of the army and military strategies. But he often exaggerates this historical information and mixes it with literary tropes, as in the opening of the Humayun-Sur clash:

When he saw the Lord of the Earth come to the battlefield, King Humayun ordered two thousand heroes into battle. Thinking to himself, 'how can two or three sparks not turn to ash many bundles of grass?' he stood ready with a detachment of his own troops. He caused those nine lakh of incomparable soldiers to become engulfed in confusion and overwhelmed by scores of warriors who were releasing arrows like deep clouds pouring forth rain. How can two or three proud lion cubs not ward off the pride of crores of elephants? How can two or three drops of immortal nectar not banish a tough, incurable disease? ${ }^{23}$ 
Here Padmasāgara claims that 2000 Mughal soldiers used arrows to defeat 900,000 Surs. He no doubt amplifies the factor by which Humayun's troops were outnumbered but still finds it useful to provide concrete numbers. He also brings to life the strength of Humayun's meager army through a series of metaphors in which the smaller party is actually the stronger one (baby lions still scare an elephant, and sparks of fire raze heaps of grass).

Scholars have frequently been discomforted by such mixings of literary and historical impulses in premodern Indian texts and accordingly have tried to parse fact from fiction in various ways. In their influential book Textures of Time, Narayana Rao, David Shulman and Sanjay Subrahmanyam suggest paying close attention to the temporal, lexical and narrative textures of early modern works in order to more accurately gauge which ones are 'clear alternative modes of historiography, narrowly conceived' versus those which are 'located elsewhere in the cartography of historical reimaginings'. ${ }^{24}$ They articulate this viewpoint in contrast to long-standing and oft-repeated condemnations of India as lacking any historical consciousness. ${ }^{25}$ Arguing against the same notion of a lack of 'history', scholars such as Ramya Sreenivasan and Prachi Deshpande have found it more useful to treat Indian sources within the loosely defined category of 'historical memory' and analyze their representations of reality rather than contest their veracity. ${ }^{26}$ These methodologies have usefully drawn attention to the diversity of historical imaginaries in early modern India. The latter approach has proved particularly fruitful in recovering not what we judge to be accurate reports, but rather what authors perceived to be relevant narratives of prior times. Nonetheless in emphasizing either finding objective truth or placing Indian texts outside of such a domain, many have failed to consider the possibility that the modern divide between history and literature may have been absent altogether in many South Asian traditions.

Padmasāgara's work attests that writing about the past was deeply relevant to early modern Sanskrit intellectuals but that such accounts were also unequivocally aesthetic projects. Recently, Kumkum Chatterjee has suggested that premodern Indian authors conceptualized a 'close, virtual inseparability of pre-modern historiography with kavya'. ${ }^{27}$ Padmasāgara's narrative suggests that we should extend this point even further to erase the long assumed partition between history and poetry altogether. As Sheldon Pollock has put it: 'Perhaps, instead of assessing whether Indian texts are history or myth, we might ask whether the texts themselves invite us to transcend this very dichotomy. ${ }^{28}$ Within an undivided genre of historical narrative, Padmasāgara further complicates his relationship to the past by exploring the flexibility of written history in premodern India and modifying significant aspects of the Mughal story.

Although Padmasāgara's account of the Humayun-Sur battle remains historically grounded insofar as Humayun did fight a Sur ruler in order to (re)gain Delhi, he nonetheless alters several features of the conflict to create an event that is difficult to square with contemporary Persian accounts. Most glaringly, Padmasāgara identifies Akbar as an 8 yearold boy when Humayun marches to Delhi, which dates this encounter to 1550-1551. But multiple Persian sources attest that Humayun was fully occupied during this time with intra-family skirmishes around Kabul. ${ }^{29}$ Humayun only definitively wrested Kabul from his half-brother Kamran in 1553 and did not find an opportunity to re-enter India until 1554, after the death of Islam Shah Suri. We might excuse Padmasāgara as merely confusing Akbar's age at the beginning of the journey to Delhi, but he correctly states it when Akbar assumes the throne. ${ }^{30}$ Moreover, Padmasāgara provides several further indications that his intention was to elide completely the temporary forfeiture of Mughal India to the Sur dynasty. 
Padmasāgara muddles the identity of Humayun's opponent in this conflict to transform what was actually a defeat for the Mughal king into a victory. There were as many as seven Sur rulers in their 15-year reign over parts of north India. ${ }^{31}$ Padmasāgara does not name Humayun's foe beyond 'Sur' but does specify that this king defeated Maldeo of Jodhpur, a feat that Persian sources unanimously attribute to Sher Shah Suri in 1543-1544. ${ }^{32}$ Sher Shah died in 1545, and Humayun retook Delhi in 1555 from Sikandar Sur. ${ }^{33}$ In the Persian record, Humayun's only direct encounter with Sher Shah Suri was in 1540 when the latter usurped the Mughal throne. Mughal authors generally speak of this event quite openly and even treat Sher Shah, whom they call Sher Khan, with respect, as he was a former Mughal general and a strong adversary. ${ }^{34}$ Gulbadan Begum, Humayun's own sister, plainly states during her discussion of Humayun's retreat from Hindustan, 'Finally, God's will was done. [Humayun's men] were caught off guard as Sher Khan poured down on them. The army was defeated'. ${ }^{35}$ But Padmasāgara turns a battle that ended in disgrace for Humayun into the foundation stone for Mughal rule from Delhi, and the battle concludes when Humayun routes his opponent and triumphantly seizes the Surs' treasury. ${ }^{36}$ Moreover, Padmasāgara omits all mention of the 15-year gap in Mughal rule, as if the so-called Sur Interregnum never happened.

After the Humayun-Sur conflict, Padmasāgara continues to rewrite history to further his vision of an uninterrupted beginning to Mughal power in India. He includes two further stories involving Humayun: his capture of Gujarat and Malwa from Bahadur Shah and his untimely death. According to multiple Persian sources, the former event unfolded in 1535-1536 and the latter in 1556 with Humayun's exile from Hindustan separating the two. ${ }^{37}$ Padmasāgara's versions of these affairs match those of contemporary Persian sources in nearly every detail, including the precise geography of the Gujarat-Malwa expedition as the action moves from Chittor to fort Mandu to Champaner to Cambay. ${ }^{38}$ His narration of Humayun's death contains significant poetic embellishment of how 'jealous fate, thinking that [Humayun] was his match, cast him down', but nonetheless accurately captures the story that, for one reason or another, Humayun fell down the stairs. ${ }^{39}$ However, Padmasāgara portrays these two events as occurring in rapid succession, after Humayun conquered Delhi for the first and only time.

Moreover, since the Humayun-Sur battle is presented as the initial Mughal conquest outside of Kabul, Jagadgurukāvya expunges Babur from the record altogether. Sumit Guha has recently called attention to the crucial role of forgetting in historical narratives and how it can irrevocably shape knowledge about past events. ${ }^{40}$ In the case of Mughal India, there was no danger of Babur being forgotten, and other Jains who wrote about imperial events frequently include Babur as a praiseworthy figure. ${ }^{41}$ But in choosing a later, indeed largely imagined point to begin Mughal rule in India, Padmasāgara condenses the trajectory of Mughal domination. According to Jagadgurukāvya's internal dating of events based on Akbar's age, only 4 years (as opposed to the actual 30) separated the Mughals' first and only conquest of Delhi from Akbar's enthronement. As we will see, Padmasāgara wanted a strong Mughal Empire for several reasons, and so he imagined it as such from the beginning.

Throughout his streamlining of Humayun's victory over India, Padmasāgara emphasizes the link between forceful Mughal expansion and broad cultural flourishing. For example, at the close of the Humayun-Sur clash, he praises Humayun for his ability to ensure freedom and wealth in the newly minted Mughal Empire.

When the Sur King had been defeated, [Humayun] made the Sur warriors his own servants who, free from punishment and happy, inhabited that land. Then he established a kingdom 
without fear where elephants, horses, oxen, camels and men traveled on the road between Kabul and Delhi and millions of houses on tall mountains were adorned with heaps of pearls, gems and gold. ${ }^{42}$

As Padmasāgara notes, the security of the Kabul-Delhi road was good for economic prosperity and individual travellers. Both were active concerns for the Gujarati Jain community, which had long been involved in trade and sought to ensure safe travel for monks and lay pilgrims. ${ }^{43}$ Indeed, later in his work, Padmasāgara details Hīravijaya's journey from town to town along Mughal roads on his way to meet Akbar. More generally, Padmasāgara also asserts that Humayun brought prosperity to Gujarat and Malwa upon their inclusion in the empire.

Having established prosperity in the great lands of Gujarat, Malwa and so forth, the Mughal ruler, abounding with a hundred virtuous qualities, came to Delhi. He possessed the best kingdom that was united, free of enemies and happy. For when good fortune itself is watching, who does not obtain everything he desires? ${ }^{44}$

After Humayun passed away in Delhi, it fell to his son Akbar to fortify imperial control. Padmasāgara portrays Akbar as first matching and then far exceeding his father in terms of both military prowess and the associated benefits to Hindu and Jain communities. First, Padmasāgara devotes several verses to how the young king warded off the still threatening remnants of the Sur elite. ${ }^{45}$ During this period, Akbar acted largely under the direction of Bairam Khan, a vicegerent (vakil) who commanded troops in the name of the juvenile ruler. ${ }^{46}$ But Padmasāgara gives no indication of this split of power and portrays Akbar as a ruthless force on his own account:

There the king, even though only twelve-years old, surrounded by the heroes of that army, came flying at the Sur's army like the star Canopus headed towards the ocean. Amazingly, he caused those warriors to wither from merely hearing a syllable of his name, and he established immortality for his troops that was like an ocean filled with the taste of victory. ${ }^{47}$

Soon, 'fragments of the Sur forces went to the house of the god of death, others to a mountain cave, some to the ocean and more to the deep forest; none remained' ${ }^{48}$

Padmasāgara next relates how, having vanquished his foes, Akbar built the crown jewel of the Mughal imperium: Fatehpur Sikri. For Padmasāgara, Fatehpur Sikri embodies the potent unity of Mughal strength and cultural prosperity.

When the king achieved total victory over that land, he established Fatehpur (phattepura), a beautiful name in the Mughals' language, just as Kṛ̣na established the city of Dvārikā full of large, beautiful palaces; for the establishment of a city in the place of victory is a royal prerogative.

Victorious Padshah Akbar rules in Fatehpur, the best of cities that is inhabited by the community of traders and shines with houses of the four Hindu castes, Jain temples, the schools of those engaged in the six philosophies and the best palaces that are inhabited by the feet of Sufis, virtuous dervishes and Mughals. ${ }^{49}$

Here Akbar's accession created a new urban space in which a diverse population of Hindus, Jains and Muslims all thrived. ${ }^{50}$ Padmasāgara's vision stands in stark contrast to other roughly contemporary visions of social cohesion under Mughal rule. For example, a Persian Sufi text composed over 20 years, between 1635 and 1654, offers a quite 
different image of the peace enacted by Mughal domination. Muzaffar Alam summarizes this work's depiction thus:

As word of the justice of Shāh Jahān spread, the people of all communities came to his lands. Even Hindus and fire-worshippers became so obedient to Islam that in each street and bazaar, the cow would be slaughtered and they would have no objection to it and even gave their daughters willingly in marriage to the emperor and his nobles. No one challenged the sovereignty of the Mughal ruler. ${ }^{51}$

In contrast, Padmasāgara celebrates that the Mughal conquests and the founding of Fatehpur Sikri enabled people of different traditions to practice their own traditions. However, once again Padmasāgara modifies the timeline. He next describes a battle over Chittor that took place in 1567, whereas Fatehpur Sikri was not founded until 1570. It seems that Padmasāgara preferred to depict Akbar, like his father, as marching out from a definably Indian city to expand his kingdom.

Akbar's siege of Chittor is the final military encounter relayed in Jagadgurukāvya and, in Padmasāgara's retelling, provides a rich commentary on the perceived relationship of power and culture in Mughal India. Padmasāgara provides a sociopolitical framework for the struggle over Chittor that references Akbar's strategy of marrying the daughters of Rajputs as a means to ensure loyalty to the Mughal crown. He introduces the practice in three verses.

\begin{abstract}
Having lifted-up a metal chain weighing hundreds of pounds ${ }^{52}$ with his bare hand, he hurls it into the sky forcefully as if it were a small ball. Does that man, Glorious Shah Akbar, fail to effect wonder in the hearts of any demonic Hindu kings on earth as he reveals their weakness? Hearing about his strength, some of the unimpaired Hindu kings give him their own daughters as requested to protect their kingdoms. Others give him presents such as arrangements of moonstones and fall before his feet, while others act like his servants. But all are subservient to him. It is said that because of shining good fortune he has thousands of lovers, the daughters of Hindus and foreigners (mleccha), who exceed goddesses in beauty. The fruits of his pleasures with those women are three lovely, favorable sons. Those few souls, due to being [his] sons, will become lords of the earth. ${ }^{53}$
\end{abstract}

Here Padmasāgara returns to his hind $\bar{u}$-Mughal dichotomy and delights in describing how Akbar forced Rajput rulers to consent to his will. Modern readers have often feared political uses of such connotations in ongoing communal tensions. ${ }^{54}$ But, for Padmasāgara, the unadulterated strength of the Mughal king in comparison to Rajput rulers serves his poem's larger vision of Mughal authority as improving society.

Padmasāgara next relates how Rai Uday Singh of Mewar refused Mughal demands for his daughter. Uday Singh defiantly proclaimed: 'My ancestors did not give their daughters to a foreigner, and so I too will not give mine. ${ }^{55}$ An armed encounter ensued, which culminated in Akbar's siege of Uday Singh's fort at Chittor and the slaughter of most of the soldiers within along with many civilians who allegedly assisted in the defence. ${ }^{56}$ Despite the reasons given for beginning this battle, Padmasāgara makes no mention of a marriage at its conclusion and instead returns to his consistent theme of elaborating the advantages of Mughal supremacy. After taking Chittor, 'King [Akbar], who possessed great concentration (samādhi) and was surrounded by his troops, spread excellent rule throughout the Rāna's land with his own steps. ${ }^{57}$ Rajput chronicles and oral legends also remember Uday Singh's refusal to marry any women of his family to the Mughals. By the nineteenth century, this Mewar policy had become proudly memorialized as a rebellious act against the degradation of Hindu women compelled to marry Muslim rulers. ${ }^{58}$ During colonial 
rule, newly hardened ideas about Hindu and Muslim identities had begun to emerge that made it politically powerful to juxtapose the two communities, particularly in violent ways. However, in the late sixteenth century, Uday Singh likely pursued this course of action as part of a strategy to negotiate internal Rajput rivalries rather than for ideological reasons. ${ }^{59}$ Padmasāgara certainly emphasizes a Mughal-Rajput clash over the marriage issue and ignores the influence of any politics between Rajput groups, but he does so for different reasons than later historiography. Here Padmasāgara found a Rajput-Mughal dichotomy to be a useful rhetorical tool in framing a conflict that demonstrated the awe-inspiring power of Akbar's army and resulted in superior rule for all.

However, one detail complicates Padmasāgara's image of a clear Mughal victory in Chittor, which is that Uday Singh lived. He fled from Chittor before Akbar seized the fort and remained at large for the rest of his life. ${ }^{60}$ However, perhaps feeling a need to explain this slight caveat to a total Mughal victory, Padmasāgara adjusts the circumstances surrounding the escape. According to Padmasāgara, Akbar caught Uday Singh but decided to free him because Akbar 'feared sin' (päpabhīrukatayā) and 'having sinned once was afraid in his heart of doing so again'. ${ }^{61}$ Just before this Padmasāgara notes the devastation that followed Akbar's sack of Chittor, including the massacre of so many that rivers of blood flowed everywhere. He reports that Akbar 'became filled with compassion (kärunya)', which had long been a mark of a Jain king. Akbar then repented of causing such devastation, particularly the slaying of civilians, and berated himself, saying, 'Alas! Have I done something worse than the action of an outcaste (candāla)? ${ }^{\prime 62}$ Here Padmasāgara briefly transitions from presenting Akbar as beneficial for Jain community interests to characterizing him as an actual religious adherent. ${ }^{63}$ In addition to recasting Uday Singh's escape as a merciful release, this strategy had the added benefit of justifying Padmasāgara's positive portrayal of the Mughals to sceptical Jain readers, and later authors pursued this tactic more aggressively. ${ }^{64}$ For Padmasāgara, imagining Akbar as a Jain constitutes a short digression from his more consistent discourse on the widespread prosperity associated with Mughal sovereignty.

To close his account of Mughal victories, Padmasāgara offers a final assessment of the favorable cultural and social conditions that resulted from Akbar's actions.

Thus, having conquered the ruler of Gujarat, whose wealth was Mewar and Malwa, King Akbar happily returned to his own city. Shrewd in all ways and skilled in the means of rule, he protected his kingdom and offered respect to learned men with correct views because he desired to hear their teachings. ${ }^{65}$

This image of a golden age brought about through imperial might combined with illustrious rule set the stage for Hiravijaya's entry into the Mughal court.

\section{Imperial and religious contexts of Jagadgurukāvya}

Several crucial contexts help further clarify the nature of Padmasāgara's project and the ambitions behind his Sanskrit history of early Mughal India. In large part, Padmasāgara was responding to Akbar's victory over Gujarat in 1572-1573 and the subsequent proliferation of Jain connections with the imperial court. In this environment, many Jain authors felt compelled to address the growing influence of the Mughals, although Padmasāgara's account differed from others in several respects. His ties to a particular Jain sect, the Tapā Gaccha, also shaped his project, and he envisions Mughal authority as offering a template for articulating the aspirations of his religious community. He deploys the conceptual and aesthetic tools of the Sanskrit literary tradition to cultivate a dynamic 
historical consciousness that speaks to live issues within his political, social and religious milieus.

The Mughals seized Gujarat in 1573 from the nominal control of Muzaffar Shah III and integrated the area into the empire over the course of the next two decades. Jains in western India had long involved themselves in the business of government under both Muslim and Hindu rulers, and the strength of the Mughals offered unprecedented political prospects. Tapā Gaccha members in particular pushed a multifaceted agenda with the Mughal rulers. They lobbied for the release of Gujarati prisoners captured during the Mughal invasion, royal decrees banning animal slaughter for certain periods of time and administrative control over contested pilgrimage sites. ${ }^{66}$ Padmasāgara celebrates several of these imperial measures in his work, particularly the effective enforcement offered by the Mughals. For example, after noting that Akbar agreed to Hīravijaya's request to prohibit fishing in a particular lake near Fatehpur Sikri, he observed that '[glorious Padshah Akbar] ordered servants to sound drums throughout the city in order to inform all the people and secretly appointed men to arrest those who violated the rule'. ${ }^{67}$

Despite trumpeting such political gains, Padmasāgara avoids dwelling on the event that prompted strong Jain-Mughal relations: the 1573 takeover of Gujarat. He does not narrate this battle in his work and only mentions Akbar 'having conquered the ruler of Gujarat' in passing at the conclusion of the clash over Chittor fort. ${ }^{68}$ This omission is striking on several accounts. First, Padmasāgara's version of Mughal history is primarily a series of armed conflicts, and so one wonders why he glosses over the most critical one to explaining why he is writing about the Mughals at all. Moreover, Padmasāgara seems to have the perfect opportunity to discuss this event when he lauds Fatehpur Sikri, which was named the 'city of victory' to honour Akbar's triumph over Gujarat. Last, Gujarat was a standard conquest for Jain literati to highlight when discussing the Mughals in Sanskrit, even when they referenced few other military events. ${ }^{69}$ One reason why Padmasāgara declines to elaborate on Akbar's incursion into Gujarat may be that it would upset his adjusted timeline. Persian histories relate that Humayun lost Gujarat shortly before Sher Shah Suri forced him out of India and Akbar later regained the area. Since Padmasāgara elides over the Sur Interregnum, he implies that the Mughals never relinquished control of Gujarat after Humayun's initial victory. Along these same lines, Padmasāgara also fails to mention the second Mughal loss of Gujarat in 1583, only a few years before he completed his poem, when Muzaffar Shah III briefly recovered his kingdom. ${ }^{70}$

Although Padmasāgara neglects Akbar's ventures into Gujarat, his Jagadgurukāvya nonetheless exemplifies how deepening connections with the Mughal court impacted the Tapā Gaccha community. Padmasāgara initiates the trend of writing biographies of Jain figures that pursued imperial associations, as I elaborate below. Additionally, beginning with Padmasāgara, Tapā Gaccha intellectuals perceived their leader and community in direct relationship to Akbar and the Mughal Empire. Padmasāgara concentrates on Hirravijaya's time at the Mughal court at the expense of all other events in his life. Aside from the 40 verses at the beginning of the text that largely outline Hiravijaya's childhood, Jagadgurukāvya is devoted to episodes related to the Mughals, of which Akbar's meeting with Hīravijaya is paramount. Padmasāgara opens his section on Mughal martial feats with Akbar hearing about Hīravijaya's great fame.

One time, Hīravijaya Sūri, ornamented by a multitude of ascetics, stayed in the city of Gandhara for the duration of the rainy season. I will narrate all this: how the King of Delhi heard about him, and he was called and received by good people devoted to non-violence towards all life. ${ }^{71}$ 
After his foray into military history, Padmasāgara returns to the account of how Akbar summoned Hiravijaya from Gandhara to Fatehpur Sikri in 1582. This initial encounter is recorded in several other Sanskrit and vernacular texts as well, which agree on the basic outline of the meeting: the two exchanged pleasantries, Hiravijaya taught Akbar about Jain dharma and the king granted him political favours. ${ }^{72}$ Padmasāgara dedicates nearly as much of his text to this episode as he does to military activities. He also briefly notes a few other royal concessions gained by Hïravijaya at a later date, such as financial assistance for the maintenance of Jain temples, before he closes with more general praises of the Tapā Gaccha leader. $^{73}$

In focusing on Hīravijaya's imperial affiliations, Padmasāgara participates in a longstanding Śvetāmbara tradition of emphasizing the positive reception of ascetics at court. ${ }^{74}$ Tapā Gaccha authors in particular laud Jagaccandra, the thirteenth-century founder of the group, for receiving the title of tapa (pious ascetic) from the Rāja of Mewar. ${ }^{75}$ This epithet, which signifies a robust devotion to ascetic practices, became the namesake for the entire community going forward. Hiravijaya also gained a royally bestowed title when Akbar fashioned him jagadguru (teacher of the world). Devavimala, Hiravijaya's other Sanskrit biographer, mentions the titles of Jagaccandra and Hiravijaya in succession in order to underscore the continuity in the Tapā Gaccha's links with kings. ${ }^{76}$ For his part, Padmasāgara invokes Hīravijaya's appellation in the title of his text and proudly proclaims that Akbar named Hiravijaya as the teacher of the world 'before the elite in his own assembly, having articulated [Hïravijaya's] virtues that have purified [Akbar's] own mind'. ${ }^{77}$

Despite the tradition's long-standing ties with royal milieus, Jains often felt uncomfortable with the idea of monks attending court, which emerges in other texts on Jain-Mughal relations. For example, Jagadgurukāvya was followed by Devavimala's far longer biography of Hīravijaya, entitled Hìrasaubhāgya (Hïravijaya's Good Fortune), which spearheaded the trend of deifying the Tapā Gaccha leader after his death. ${ }^{78}$ Devavimala also addresses Hīravijaya's meeting with Akbar, but he devotes a much smaller proportion of his text to imperial affairs than Padmasāgara. ${ }^{79}$ Crucially, Devavimala exhibits a certain amount of anxiety when writing about Hīravijaya's time at court, which many would have viewed as inappropriate for a world-renouncing monk. ${ }^{80}$ Arguably, the most detailed Sanskrit work on Jain-Mughal connections is Siddhicandra's Bhānucandraganicarita (Acts of Bhānucandra), which records events involving nearly a dozen different Jain intellectuals who operated in the Mughal milieu from the 1580s through the $1610 \mathrm{~s}$. Nonetheless, even Siddhicandra explores some deeply rooted objections to Jain relations with secular authority in the penultimate episode of his work where a disagreement between himself and Jahangir results in the temporary banishment of Jain mendicants from the Mughal Empire. ${ }^{81}$

Padmasāgara, however, displays little unease in this regard and moreover seeks to elevate Hīravijaya precisely by employing tropes used to express kingly authority. For example, Padmasāgara frequently equates Hiravijaya and Akbar during their meeting, using paired epithets such as 'king of the earth' and 'king of monks'. ${ }^{82} \mathrm{He}$ also describes Hiravijaya's travels to the Mughal court in detail as the monk traverses through different cities and areas. ${ }^{83}$ In large part, Hīravijaya's journey is a mode of expressing domination modelled on the martial 'conquest of the quarters' (digvijaya) of Indian kings. ${ }^{84}$ Jain thinkers had long emphasized the notion of a world conqueror (cakravartin) as a central theme in discourses about secular and religious authority. ${ }^{85}$ Later Tapā Gaccha texts also adopt this strategy of describing their order as a dynasty and even represent the sect's leaders as Mughal-like warriors accompanied on their conquests by armies of monks. ${ }^{86}$ 
However, what ought to draw our attention is not only that Tapā Gaccha authors often conceptualized fluidity between the characteristics of spiritual and imperial figures but also more pointedly that Padmasāgara's paradigm was Mughal political power in particular. For example, at the conclusion of Akbar and Hīravijaya's initial encounter, Padmasāgara depicts Hīravijaya as co-opting the markers of Mughal royalty in his procession from court.

Then the Protector of the Earth [Akbar], following on foot, bowed down at [Hiravijaya's] feet and stood again. From his own home, he sent all his soldiers to [Hīravijaya], ordered musical instruments to be played stridently by men sitting on top of elephants and had his own splendor (svaśriyam) - complete with chariots, horses and elephants - go before [Hīravijaya]. ${ }^{87}$

Here Akbar sent his own royal accoutrements, those things that announced to the world that he was the Mughal sovereign, to accompany Hīravijaya. Subsequent verses depict a Tapā Gaccha king who parades through crowds of people that revel in his presence and throw expensive clothes and jewels on the ground before him. ${ }^{88}$ In these ways, Padmasāgara casts Hïravijaya as an authority figure in a definably Mughal sense, who is the equal or superior of Akbar.

In another verse, Padmasāgara makes an even stronger claim of Hīravijaya's status by comparing him with the Islamic God. One could scarcely imagine a more evident appeal to Mughal standards than invoking the Persian name of God (khudāa).

[Hīravijaya], that foremost among the dispassionate, best of ascetics, who had the form of Glorious $k h u d \bar{a}$, was seen there, the likes of whom had not been seen anywhere else on earth. ${ }^{89}$

In other words, Hiravijaya stood on the highest level of the Islamic hierarchy, one step above any earthly ruler and comparable to God himself. Akbar is often described in Persian texts as the image of God, or, more specifically in Persian, the 'shadow of God'. 90 In Hiravijaya's case, the transfer of royal, Islamic-based authority to the Jain monk is unmistakable and introduces strong Mughal cultural standards into the Sanskrit tradition.

Padmasāgara's veneration of Hīravijaya serves as a public glorifying (prabhāvanā) for the Tapā Gaccha. Such moments of acclaim were directed towards a Jain readership that would appreciate and even expect exaltations of their leader in a biographical work. ${ }^{91}$ Padmasāgara elevates his community precisely by making Hīravijaya's ties to the Mughal court a source for new standards of power and praise. Earlier Jain authors had often extolled monks by showing their influence over the reigning king, occasionally even claiming that particular rulers converted to Jainism. ${ }^{92}$ Padmasāgara hints at Akbar's Jain-like sensibilities at times, but he also allows power to transfer the other direction so that Hiravijaya is glorified by becoming like Akbar. Padmasāgara completes this shift when he proclaims Hiravijaya akin to the Islamic monotheistic God and thus operating within a world defined by Mughal paradigms of authority. We can better understand such cultural and literary choices if we place Jagadgurukāvya within a larger framework of records of the past in premodern and early modern India.

\section{Contested memory and Sanskrit history}

Jagadgurukāvya explores history in an inventive manner that speaks to the development of historical literature in Sanskrit. Scholars have long recognized that history in premodern India was quite different from how the genre was constituted elsewhere, but they remain fragmented on how to best approach this complex tradition. Padmasāgara's work is an ill fit 
with the framework outlined in Textures of Time, which proposes that literary texts use cues to signal a transition into a truth-telling mode where a trained reader knows that 'the past is being treated in a factual manner' ${ }^{93}$ Many scholars, such as Sumit Guha, have criticized the 'shaky theoretical scaffolding' of this approach and suggested that a deeper understanding of texts can be gained if we 'historicize both genre and community' ${ }^{94}$ Indeed, rather than moving between reality and fantasy, Padmasāgara exercises what Allison Busch has called 'a poet's prerogative not to record history' and instead constructs a narrative pertinent to his community. ${ }^{95}$ In so doing, he participates in an established, although still largely unexplored and misunderstood, practice of writing about the past that flourished in Sanskrit and vernacular languages in early modern India. ${ }^{96}$ Padmasāgara both followed and transformed the strategies of his predecessors to conceptualize an open dialectic between past events and literary possibilities.

Padmasāgara inherited a substantial literary tradition of crafting history from Jain and other Sanskrit authors. Jains had long collected stories in prose about their central religious figures (prabandhas, caritas).${ }^{97}$ By the twelfth century, they had begun to eulogize the lives of their leaders within poetic genres as well that exhibit some of the stylization evidenced in Jagadgurukāvya. ${ }^{98}$ The Jains also came to focus on larger historical events. For example, the fourteenth-century Hammīramahākāvya (Great Poem on Hammira) features both descriptions of the beloved Sanskrit motif of water play (jalakrī $\bar{a} \bar{a}$ ) and the 1301 battle between Alauddin Khilji and Hammira Chauhan over Ranthambhor fort. ${ }^{99}$ The wider Sanskrit tradition also infused historical events with literary idioms. In his twelfth-century Rājatarangin̄i (River of Kings), for example, Kalhana claims to present an unbiased account of the past and invoke the aesthetic quality of peace (śäntarasa). ${ }^{100}$ Despite attempts by modern scholars to establish which parts of this narrative are accurate reports versus poetic fancy, Kalhana himself offers no hint of any discord between these two objectives. ${ }^{101}$

Several Indian works also display tendencies to alter aspects of the past, a sensibility that becomes particularly highly developed in early modern Jain and vernacular materials. For example, writing his Prabandhacintāmani (Wishing Stone of Narratives) in the early fourteenth century, Merutunga omits the capture of Somanātha Patan by Mahmud of Ghazna in 1026, an event much celebrated in Persianate historiography. ${ }^{102}$ Padmasāgara's more invasive rewriting of events is paralleled in certain ways by Rajput vernacular narratives. For example, Prithvirāj Rāso, a sixteenth-century Hindi work, commemorates the exploits of Prithviraj, a late twelfth-century Rajput ruler, and his battle with Muhammad Ghori. The Rāso changes several major facets of Prithviraj's story so that he is the king of Delhi in addition to Ajmer and kills Muhammad Ghori rather than never getting his revenge and simply fading from sight. Cynthia Talbot has argued that regardless of the historical inaccuracy of such emendations, they filled acute needs in the self-identity of sixteenth-century Rajputs. ${ }^{103}$ Another useful comparison for Padmasāgara's work is the story of Padmini, an early fourteenth-century Rajput queen in Mewar who was sought after by Alauddin Khilji. Ramya Sreenivasan has shown that Padmini's plight inspired numerous divergent retellings, particularly from the late sixteenth century onwards, all of which differ from Persian records. ${ }^{104}$

These Jain and vernacular texts were generally separated from the events that they reimagined by several hundred years. In Sanskrit reworkings of Mughal history, authors also preferred to dwell upon events that were comfortably removed from them in time. For example, an early eighteenth-century Sanskrit chronicle that covers Mughal rule moves the dates of Timur forward by around 200 years, so that in 1496, 
The ruler of the Chagatai Kingdom, endowed with bravery, called Timurlang, 'whose mark is darkness' (timiralinga), first established rule in the great city of Delhi. This man ruled for 15 years, 1 month, 5 days and 8 ghatīis (one ghatī is twenty-four minutes). ${ }^{105}$

The text then begins the lineage of Mughal kings with Babur, who is labeled the second ruler after Timurlang, with no indication of the few centuries that actually separated the two. ${ }^{106}$ However, a few Sanskrit works contemporaneous with Jagadgurukävya also restructured relatively recent Mughal battles. In his 1596 Rāṣtraudhavamíamahākāvya (Great Poem on the Rastraudha Dynasty), Rudrakavi, a court poet in Baglan, describes how Bahadur Shah of Gujarat was victorious over Humayun in 1535-1536, when in reality the battle went the other way. ${ }^{107}$ Padmasāgara shifts locations, dates and details in more nuanced ways, and he also strikingly concludes with occurrences less than 10 years before his text's composition.

Padmasāgara's approach to rewriting a history temporally proximate to him suggests that brute accuracy was not his primary goal. The early modern Sanskrit tradition conceptualized the rules and purposes of writing about the past to allow for multiple, even conflicting narratives. ${ }^{108}$ For Padmasāgara, this differently calibrated historical sensibility allowed him a creative freedom in reference to the past that we typically restrict to imaginative literature today. Crucially, Padmasāgara narrates Mughal military events, particularly their conquest of India, in lieu of other pasts. He does not dwell on any of Hiravijaya's spiritual predecessors in his text and instead articulates a largely imaginary but still recognizable version of Mughal martial feats as the most pertinent backdrop for framing Hīravijaya's moment of glory at the Mughal court. Padmasāgara's interest in the military processes of empire no doubt reflects the strength of Indo-Persian power in late sixteenthcentury India, particularly from a Gujarati perspective. ${ }^{109}$ Additionally, Jagadgurukāvya marks an important moment when an intellectual formed in the Sanskrit thought world identified the development of the Mughal Empire as relevant to his own tradition of historical writing. Indeed, Padmasāgara's work marks the beginning of a substantial body of Jain-authored texts that attempted to rethink their own tradition in light of their imperial relations.

After Jagadgurukāvya, Jains produced a number of Sanskrit works that detail aspects of Mughal India and Jain-Mughal interactions. These include biographies devoted to the three successive leaders of the Tapā Gaccha from the mid-sixteenth to the mid-seventeenth centuries, all of whom visited Mughal courts. ${ }^{110}$ In addition, a work dedicated to Bhānucandra, a prominent Tapā Gaccha monk active during the late sixteenth to early seventeenth centuries, addresses Jain-Mughal relations more broadly. ${ }^{111}$ Other Jain lineages also participated in cross-cultural activities in the Mughal milieu, and a text by Jayasoma of the Kharatara Gaccha presents an account of Akbar's relations with Karmacandra, a lay Kharatara and politician of the period. ${ }^{112}$ To a lesser degree, Digambara Jains also participated in this trend, such as Rājamalla who describes the Mughal kings, the Agra bazaar and various imperial measures in two separate Sanskrit texts. ${ }^{113}$ Jains also produced a series of Gujarati works that discuss their ties with the Mughals and remain largely unresearched. ${ }^{114}$

Although Padmasāgara inaugurates this cascade of texts, later works differ significantly from Jagadgurukāvya and tend to focus on a wide range of Jain-Mughal encounters instead of military history. One likely explanation for this divergence is that Padmasāgara's account of how the Mughals came to rule India ceased to be relevant to his community soon after its composition. ${ }^{15}$ The reasons for this shift remain elusive, but the textual evidence is quite clear that Jagadgurukāvya's chronicle of conquest was superseded by texts that emphasize the activities of Jain monks at the imperial court. Regardless of his reception 
(or lack thereof), ${ }^{116}$ Padmasāgara aimed to compose a crucial work within the multilingual tradition of Indian historical writing. Like later Jain authors, Padmasāgara directs his treatment of Mughal affairs at fellow Jains, particularly Tapā Gaccha affiliates in many respects, as I discussed above. ${ }^{117}$ However, in omitting any lineage of his religious community, he perhaps also indicates a non-sectarian readership for his work. ${ }^{118}$ At the very least, he invokes the ability of the Sanskrit tradition more broadly to radically rework written accounts of the past and constructs a narrative of recent military feats that allowed Jain communities to flourish within a world defined by Mughal power.

\section{Conclusion}

Within the numerous, overlapping Indian traditions of how to write about the past, Padmasāgara developed a multifaceted mode of pursuing Jain and Sanskrit interests in history. He envisioned an alternative storyline for how the Mughals became rulers of north India that articulated the benefits of their political supremacy for his regional and religious communities. Concomitantly with this project, he reformulated how Jain authority operated in early modern India so that the Mughal environment inflects Hiravijaya's claims to power. Last, Padmasāgara deemed Mughal victories a pertinent topic to investigate within Sanskrit poetry because this narrative served an emerging cultural need to see recent political changes as a crucial part of his community's history. Accordingly, he simultaneously developed the potential of Sanskrit literary sensibilities to alter the recent past and explored the increasing relevance of the Mughal imperial project within the Sanskrit historiographical tradition.

In addition to furthering our understanding of early modern historical approaches, Jagadgurukāvya is also a crucial text for reconstructing the diversity of responses to Indo-Islamicate power found within Sanskrit texts. Many scholars have identified largescale tendencies of Sanskrit literati in reacting to the advent of Indo-Islamicate dynasties. Sanskrit authors categorize Muslims according to ethnic terms already in use rather than characterizing them as a new religious group. ${ }^{119}$ Sanskrit intellectuals within certain disciplines, notably grammarians and astrologers, had long been receptive to outside influences and engaged with Perso-Islamic traditions in creative ways, such as by developing bilingual lexicons and composing Sanskrit treatises on Islamicate astrolabes. ${ }^{120}$ However, beyond these select realms of engagement, exclusion was the overarching phenomenon. The philosophical tradition generally declines to admit Islam as a serious participant in dialogues between the different schools of thought, and the Sanskrit literary tradition offers no open admission of Persianate aesthetics. Scholars such as Sheldon Pollock and Christopher Minkowski have suggested specific developments that may have resulted from contact between Sanskrit intellectuals and Persianate culture, including Jagannātha Paṇititarāja's expression of personal sorrows in his seventeenth-century poetry and Sūryadāsa's invention of bidirectional poetry in Sanskrit in the late sixteenth century. ${ }^{121}$ But notably, neither Brahmanical author divulges cross-cultural inspirations for his innovation, and instead both present themselves as working exclusively within the Sanskrit tradition. Likewise, aside from Jains, Sanskrit literati who frequented the Mughal courts overwhelmingly did not write about their experiences in any detail.

In contrast to this general reticence to directly addressing changing realities, Padmasāgara and later Jain authors writing in Sanskrit exercise an alternative approach and openly discuss the new connections forged by Jain and Mughal elites. Padmasāgara, in particular, further explores how to represent Mughal domination in a historically grounded narrative that builds up to such cross-cultural events. In doing so, he frames 
the development of Mughal imperial power as crucial to understanding contemporary religious, social and regional developments. More broadly, Padmasāgara demonstrates that the Sanskrit literary tradition, at least in the hands of its Jain participants, could engage with the Indo-Islamicate world in dynamic ways. There were certainly economic and social factors, such as trading ties and a long history of contact with Islamicate dynasties, that informed the Jain perspective, even as Brahmans typically felt more constricted. For his part, Padmasāgara envisioned Sanskrit literature and imperial history as a productive combination that enabled him to craft a new joint narrative of the Mughals' rise to power and Jain cultural flourishing in early modern India.

\section{Acknowledgements}

For their feedback on earlier versions of this work, I thank Sheldon Pollock, Hamsa Stainton, John Cort, and participants in the panel 'Old Voices, New Visions: Reinterpreting Jain Perspectives in Early Modern India' at the 2011 Association for Asian Studies Conference. This research was supported by a Fulbright Hays Doctoral Dissertation Research Abroad Fellowship and a Mellon/ACLS Dissertation Completion Fellowship.

\section{Notes}

1. Pollock, 'New Intellectuals in Seventeenth-Century India' and Bronner, 'What Is New and What Is Navya'. In addition, see the many articles that emerged from the Sanskrit Knowledge Systems Project (http://www.columbia.edu/itc/mealac/pollock/sks/papers/index.html). In certain areas, such as philosophy, scholars such as Ganeri and Minkowski have identified a newness in terms of substantive thought, although frequently in the seventeenth century and later (Ganeri, Lost Age of Reason and Minkowski, 'Advaita Vedānta in Early Modern History').

2. O'Hanlon, 'Brahman "ecumene” of Mughal India'.

3. Truschke, 'Cosmopolitan Encounters', 151-75. In addition, see Paul Dundas's discussion of the origins of the Tapā Gaccha and the community's transformation with Hīravijaya and his memory (History, Scripture and Controversy, chap. 1-2).

4. On Mughal imperial orders (farmāns) given to Gujarati Jains, see Commissariat, 'Imperial Mughal Farmans in Gujarat', 1-56; Desai, introduction to Bhānucandraganicarita, Appendix 2, 77-91; Findly, 'Jahāngīr's Vow of Non-Violence', 253; and Sastri, Ancient Vijñaptipatras, 19-42. Several relevant Tapā Gaccha inscriptions are given in Epigraphia Indica, Vol. 2, 34-86 (Buhler, 'Jaina Inscriptions from Śatrumjaya').

5. For overviews, see Gopal, 'The Jain Community and Akbar' and Prasad, 'Akbar and the Jains'.

6. Bhänucandraganicarita 2.67-71, and 2.106-9. Akbar's recitation of the names of the sun in Sanskrit is also recorded in the Persianate tradition ( $\bar{A}$ ' $n$ - $i$ Akbarì, 367; Muntakhab alTavārīkh, Vol. 2, 260-1 and 322).

7. Bhänucandraganicarita 2.140-68. Compare with the record of this event in Jayasoma's Mantrikarmacandravamiśávalīprabandha, vv. 359-65. English discussions include Desai, introduction to Bhānucandraganicarita, 30-2 and, more recently, Andhare, 'Imperial Mughal Tolerance of Jainism', 223-4.

8. I reconstruct these cross-cultural titling practices in my dissertation, Truschke, 'Cosmopolitan Encounters', 95-105.

9. Jagadgurukāvya, v. 1 (kāvyam . . hìrāhvasmṛti). Unless otherwise indicated, all translations are my own.

10. Jagadgurukāvya, v. 233.

11. Compare lists of Padmasāgara's works in New Catalogus Catalogorum, Vol. 11, 150-1; Kansara, introduction to Tilakamañjarīkathoddhārah, 19; Sheth, Jainism in Gujarat, 276. Kansara discusses the disputed authorship of Tilakamañjarikkathoddhārah in particular (19-20).

12. Hīravijaya's life inspired both Sanskrit and Gujarati biographies (Sanskrit: Padmasāgara's Jagadgurukāvya and Devavimala's Hīrasaubhāgya; Gujarati: Rsạhadāsa's Hīravijaya Sūri Rāsa, dated 1629). 
13. For example, a recent set of articles in South Asian History and Culture (2011) sought to 'explore the relationships between religion, society and politics in India in the era of the Mughal Empire' (O'Hanlon and Washbrook, 'Religious Cultures in an Imperial Landscape', 133).

14. Early Mughal history is known from numerous imperial texts, which are solidly corroborated by non-Mughal sources.

15. Jagadgurukāvya, vv. 41-2.

16. E.g., Kṛpārasakośa of Śānticandra, vv. 8-17. On Hindus in central and western Asia, see Alam, 'Trade, State Policy and Regional Change', 203-5 and 211-12.

17. Babur sets the tone for understanding India and Central Asia as discrete places in his memoir, which is divided according to place and quite explicitly frames the first Mughal king as a foreign conqueror of Hindustan (Dale, Garden of the Eight Paradises, 149 and chap. 6). On how their ancestral lands played vividly in the minds of Mughal kings through Shah Jahan, see Foltz, Mughal India and Central Asia, chap. 7. Akbar retook Kabul in 1585, but it remained a frontier rather than the centre of Mughal India (see Faruqui, 'Forgotten Prince', 487-523).

18. Ernst discusses the nuances of hindū in Perso-Islamicate conceptions of Indian religions in Eternal Garden, 22-9.

19. Talbot, 'Inscribing the Self', 700 .

20. Wagoner, 'Sultan among Hindu Kings', particularly 861-3. Talbot concurs with this interpretation ('Inscribing the Self', 700-1). Compare to some more religiously twinged fourteenthseventeenth century uses of hindū in Indo-Persian (Ernst, Eternal Garden, 25-6).

21. Jagadgurukāvya, v. 87 (hindvāsurakșmāpānām). Dundas also draws attention to this passage in 'Jain Perceptions of Islam', 36. Note that although Padmasāgara condemns Rajput kings as militarily and morally inferior to the Mughals, his characterization of them as 'demons' (assura) appears to stand apart from this criticism. He praises Humayun as 'a demonic incarnation among enemies' (daityāvatāro 'rișu; Jagadgurukāvya, v. 43). Thus, the descriptor 'demonic' may simply mark both groups as non-Jain (particularly to a Jain readership) or perhaps is used to highlight their formidable military might.

22. Jagadgurukāvya, v. 44. The comment on Akbar's ascension being assured likely references the earlier capture of Akbar by Mirza Kamran and Humayun's subsequent rescuing of the prince (Tazkirat al-vāghi 'ät, 138-41, in English, and 164-7, in Persian).

23. Jagadgurukāvya, vv. 51-2.

24. Rao, Shulman, and Subrahmanyam, Textures of Time, 79.

25. Ibid., 1. Such dismissals stretch from the eleventh century with al-Bīrūnī through the colonial era (respectively, Alberuni's India, vol. 2, 10-11 and Bell, Victorian Visions of Global Order, 193-6). Also see Chatterjee's discussion in History in the Vernacular, 1-2.

26. Sreenivasan, Many Lives of a Rajput Queen and Deshpande, Creative Pasts, respectively.

27. Chatterjee, Cultures of History, 8.

28. Pollock, 'Pretextures of Time', 377.

29. Ray and Beg, Bairam Khan, 98-101. Akbar was born in mid-October, 1542.

30. Padmasāgara says that Akbar is 12 years old when he assumes the throne (Jagadgurukāvya, v. 82).

31. Discrepancies in numbers arise depending on how one calculates the short and disputed tenures of some of the later Sur kings.

32. Siddiqi, Shershah Sur and His Dynasty, 100-1; Tārīkh-i Shīr Shāhī of Sarvānī, 654-7.

33. Tazkirat al-vāghi 'āt, 169-70, in English, and 207-8, in Persian; Tärīkh-i Humāyūn, 93-4, in English, and 117-18, in Persian.

34. I am indebted to Catherine Asher for this observation, particularly in reference to Akbarnāmah.

35. Humāyūnnāmah, 29, in English, and 27, in Persian (Thackston's translation).

36. Jagadgurukāvya, vv. 45-58.

37. For an overview of Humayun's conflict with Bahadur Shah, see Hasan, State and Locality, $16-20$.

38. Jagadgurukāvya, vv. 60-74. Compare to Humāyūnnāmah, 27-8, in English, and 25-6, in Persian, and Tazkirat al-vāghi 'āt, 75-8, in English, and 81-4, in Persian.

39. Jagadgurukāvya, v. 75.

40. Guha, 'Frontiers of Memory'. 
41. For example, Śānticandra's Krpārasakośa, vv. 18-20 and Padmasundara's Akbarasāhiśringāradarpana, v. 2.

42. Jagadgurukā̄vya, v. 59.

43. Sheikh, Forging a Region, particularly $139-43$ and 153-4.

44. Jagadgurukāvya, v. 74.

45. Ibid., vv. 77-83.

46. Bairam Khan's regency lasted 1556-1560 (Husain, Nobility under Akbar and Jahāngīr, 16-20).

47. Jagadgurukāvya, v. 82 .

48. Ibid., v. 83a-b.

49. Ibid., vv. 84-5. Śophī is Sufi and daraveśa dervish.

50. It can be tempting to see this type of rhetoric as continuing the unhelpful modern glorifications of Akbar's rule as a time of great religious harmony, but the two are not connected.

51. Alam, 'Debate Within', 150.

52. Literally 'weighing thirty-two manas', likely taken from the Persian man (maund).

53. Jagadgurukāvya, vv. 87-9. Mleccha is not meant in a negative sense here, which is a usage also seen elsewhere during this period (Chattopadhyaya, Representing the Other? 50-4).

54. For example, Nicholson, Unifying Hinduism, 201-3. In addition, see Pollock's analysis of various invocations of the Rāmāyana in 'Rāmāyana and Political Imagination', 261-97.

55. Jagadgurukāvya, v. 90b-c.

56. Akbarnāmah also notes that Mughal troops killed scores of civilians during the Chittor campaign (Vol. 2, 321-4). For a description of this battle, see Streusand, Formation of the Mughal Empire, 57-61.

57. Jagadgurukāvya, v. 120a-b.

58. Talbot, 'Mewar Court's Construction of History', 24.

59. Taft, 'Honor and Alliance', 230-2.

60. Uday Singh died in 1572.

61. Jagadgurukāvya, v. 120c-d.

62. Ibid., v. $118 \mathrm{a}-\mathrm{b}$.

63. John Cort presents the idea of a continuum of Jain perspectives on kingship that range from a non-Jain king who patronized the community to a king such as Kumārapāla who converted ('Who Is a King?' 85-106).

64. For example, see Śānticandra's Kṛpārasakośa and Devavimala's Hīrasaubhāgya.

65. Jagadgurukāvya, v. 121.

66. For example, see Padmasāgara's mention of the concessions gained by Hiravijaya (Jagadgurukāvya, vv. 182-7). Persian sources corroborate that Akbar banned animal slaughter at times in deference to Hīravijaya Sūri's request (see farmān printed in introduction to Krpārasakośa, 35-8).

67. Jagadgurukāvya, v. $185 \mathrm{c}-\mathrm{d}$.

68. Ibid., v. 121.

69. For example, see Bhānucandraganicarita 1.64 .

70. The major histories of Akbar's reign, including Akbarnāmah and Muntakhab al-Tavārīkh, describe the loss of Gujarat and how 'Abd al-Rahịm Khān-i Khānān, a Mughal general, again drove out Muzaffar Shah III. The Mughals also clashed with the Portuguese in Gujarat, who controlled several key ports, during the early 1580s (Digby, 'Bāyazīd Beg Turkmān's Pilgrimage', 160).

71. Jagadgurukāvya, v. 40.

72. Padmasāgara's Jagadgurukāvya, vv. 122-89; Devavimala's Hīrasaubhāgya, chap. 13-14; Hemavijaya's Vijayapraśastimahākāvya, chap. 9; Siddhicandra's Bhānucandraganicarita 1.78-128; Ādīśvara inscription in Epigraphia Indica, Vol. 2, \#12, vv. 14-24. Akbar's official court history lists Hīravijaya as one of the learned men of the age ( $\bar{A}$ ' $\bar{l} n-i$ Akbari, 218).

73. Jagadgurukāvya, v. 199.

74. For an overview, see Cort, 'Who Is a King?' $85-106$.

75. Dundas, History, Scripture and Controversy, 41. Although the Tapā Gaccha traces its lineage back to Mahāvīra himself, Jagaccandra is one of the earliest concrete figures.

76. Hìrasaubhāgya 14.203-5.

77. Jagadgurukāvya, v. 197. 
78. Hìrasaubhägya is a mahākāvya (great poem) that stretches to 17 lengthy chapters and is accompanied by an auto-commentary. The work is undated; for estimates, see Vrat, Glimpses of Jain Sanskrit Mahākāuvyas, 92, and Dundas, History, Scripture and Controversy, 59. For a literary analysis, see Vrat, Glimpses of Jain Sanskrit Mahākāvyas, 91-108; for a more religiously focused interpretation, see Dundas, History, Scripture and Controversy, 58-72.

79. References to the Mughals span chapters 10-17 of Hirasaubhägya with chapters 13-14 devoted to Akbar and Hīravijaya's meeting.

80. Granoff, 'Authority and Innovation', 48-60.

81. Bhānucandraganicarita 4.237-337. For a summary in English, see Desai, introduction to Bhānucandraganicarita, 52-8. On the Jains' fall from imperial favour, see Findly, 'Jahāngīr's Vow of Non-Violence', 253-5, and Jahangir's own comments in Jahāngīrnāmah, 245-50.

82. For example, see Jagadgurukāvya, v. 174a.

83. Jagadgurukāvya, vv. 136-59.

84. Dundas, History, Scripture and Controversy, 24.

85. Cort, 'Who Is a King?' 98.

86. Most notably the seventeenth-century scholar Meghavijaya in his Digvijayamahākāvya (Dundas, History, Scripture and Controversy, 24; see pp. 188-9, note 29, for references to similar depictions in other texts).

87. Jagadgurukāvya, v. 189.

88. Ibid., v. 191. These images follow closely on the model of earlier monk-king pairs in the Jain tradition (on Jayasimha Siddharāja's relations with Kharatara monks, see Cort, 'Who Is a King?' 89-94, and on Hemacandra and Kumārapāla, see 96-102).

89. Jagadgurukāvya, v. 139a-b. Other Jain texts also describe Hīravijaya as 'like an image of God' but use the Sanskrit term parameśvara (Hìrasaubhāgya 13.125a).

90. Zill-i 'allāh or zill-i khudā was a common epithet for Islamicate kings, and the phrase comes up several times in Abū al-Fazl's writings, including in his collected sayings of Akbar in $\bar{A}$ ' $\bar{n}$ - $i$ Akbarī.

91. On prabhāvanās, see Cort, 'Genres of Jain History', 487-8.

92. Sheikh, Forging a Region, 162-4.

93. Rao, Shulman, and Subrahmanyam, Textures of Time, 5.

94. Guha, 'Speaking Historically', 1090 and 1091, respectively.

95. Busch, 'Portrait of a Raja in a Badshah's World' (emphasis in original).

96. Daud Ali describes how historical writing had become fluid across various genres by this time in India ('Indian Historical Writing, 600-1400', 4-7).

97. Granoff discusses the variety of biographical writings in Śvetāmbara Jainism in 'Biographical Writings', particularly 132-3. On prabandhas, see Cort, 'Genres of Jain History', 486-8.

98. See list of mahākāvyas in Cort, 'Genres of Jain History', 499, note 30.

99. For a discussion of Hammìramahākāvya, see Bednar, 'Conquest and Resistance in Context', 192-208, and Prabha, Historical Mahākāvyas, 291-319.

100. Kalhana's Rājataranginīi, 1.7 and 1.23 , respectively.

101. For example, Rao, Shulman, and Subrahmanyam, Textures of Time, 254-60. Slaje also suggests that we can distinguish between the literary 'style' and historical 'content' of Kalhana's work (Medieval Kashmir, 7-8). Zutshi offers an overview of modern treatments of Räjatarainginī ('Translating the Past', 6-8).

102. Tawney, preface to the Prabandhacintämani, xi. Thapar discusses how Jain texts tend to treat this raid and other events involving Islamicate figures in Somanatha, 105-45.

103. Talbot, 'Mewar Court's Construction of History', 25. Busch has similarly suggested that courtly Braj Bhāsā and Rajasthani narratives reflect the political interests of their intended audiences ('Portrait of a Raja in a Badshah's World').

104. Sreenivasan, Many Lives of a Rajput Queen, 22-116.

105. Rajjavamsavarnana, fol. 9a, vv. 2-3 (for Timur's date, see fol. $8 \mathrm{~b}$ ). The text is undated but offers Mughal history going through Aurangzeb's reign with a perhaps later addition of events through the time of Jahandar Shah (r. 1712-13).

106. Räjavamsavarnana, fol. 9a, v. 4 .

107. Rāstraudhavamśamahākāvya, chap. 6; in addition, see Bruyne's discussion in Rudrakavi's Great Poem, 45-6.

108. Although this lenience did not mean that intellectuals never criticized their predecessors for making mistakes (e.g., Kalhana's Räjatarangiṇī, 1.12-13). There were also more 
direct importations of Persianate histories into Sanskrit that stand apart from Padmasāgara's project, such as a Sanskrit abridgement of Akbarnāmah by Maheśa Thakkura titled Sarvadeśavrttāntasañgraha.

109. Padmasāgara may also have been influenced, albeit indirectly, by Indo-Persian historiography that often focused on state formation (Mayaram, Against History, Against State, 78-9). Busch suggests a similar influence of the Persian tārīkh tradition on Braj Bhāṣā writers (Poetry of Kings, 90).

110. Hìravijaya was the leader of the Tapā Gaccha (pattadhara) from 1544 to 1596 (Dundas, History, Scripture and Controversy, 53). Vijayasena succeeded him and died in 1615 (Commissariat, History of Gujarat, Vol. 2, 263, note 22); Hemavijaya's Vijayapraśastimahākāvya (Great Poem in Praise of Vijayasena) is devoted to him. Vijayadeva succeeded him and died in 1656 (Dundas, 'Jain Perceptions of Islam', 45, note 30); Vallabha Pāthaka's Vijayadevamāhātmya (Greatness of Vijayadeva) details his life.

111. Siddhicandra's Bhānucandraganicarita.

112. Jayasoma's Mantrikarmacandravamiśāvaliprabandha.

113. Rājamalla's Lātūisamhitā and Jambūsvāmicarita.

114. On Gujarati texts that address Jain encounters with the Mughals, see Mehta, 'Akbar as Reflected in the Contemporary Jain Literature in Gujarat'; Desai, introduction to Bhānucandraganicarita, 32, note 39; Marshall, Mughals in India, \#817 and \#938. Vidyavijayji draws upon Rụabhadās's Hìravijaya Sūri Rāsa in his A Monk and a Monarch (first published as Surishwar ane Samrat in Gujarati).

115. Sreenivasan discusses how communities discard memories no longer perceived as relevant (Many Lives of a Rajput Queen, 6).

116. Few manuscripts copies of Jagadgurukāvya are known to survive today and are housed primarily in Jain libraries in Gujarat. To date, I have identified five extant manuscripts. Two are held in the Hemachandra Jnana Mandir in Patan (nos. 2859 and 17474), one in a Jain library in Baroda (Chani 1511, listed in New Catalogus Catalogorum, Vol. 7, 129), one in the Oriental Institute of Baroda and one in a Jain library in Agra (Marshall, Mughals in India, \#1441).

117. In his analysis of Hirrasaubhägya, Paul Dundas argues that Jain works on events involving the Mughals were intended for consumption in sectarian circles (History, Scripture and Controversy, 60-1 and 71-2).

118. The lack of any explicit lineage in Jagadgurukāvya may also indicate that Padmasāgara wrote for a non-sectarian community as opposed to for Tapā Gaccha affiliates alone (I am grateful to John Cort for this suggestion).

119. See discussion in Chattopadhyaya, Representing the Other? 28-60.

120. On Sanskrit language analyses of Persian, see Sarma, 'From Yāvanī to Samskrtam', 71-88, 'Sanskrit Manuals for Learning Persian', 1-12, and 'Teach Yourself Persian the Sanskrit Way'. On astrolabes, see Sarma, 'Bilingual Astrolabe from the Court of Jahangir', and on crosscultural astrology more generally, see Pingree, From Astral Omens to Astrology, 79-90.

121. Respectively, Pollock, 'Death of Sanskrit', 408-12, and Minkowski, 'On Sūryadāsa', 325-33. Minkowski has also suggested that early modern Advaita Vedanta intellectuals were increasingly preoccupied with questions that also found parallels in Islamic thought ('Advaita Vedānta in Early Modern History', 222-3).

\section{References}

\section{Primary Sources}

$\bar{A}$ 'inn-i Akbarī of Abū al-Faẓl ibn Mubārak. Ed. Sir Sayyid Ahmad. Aligarh: Sir Sayyid Academy, Aligarh Muslim University, 2005.

Akbarasāhiśrningāradarpana of Padmasundara. Ed. K. Madhava Krishna Sarma. Bikaner: Anup Sanskrit Library, 1943.

Akbarnāmah of Abū al-Fazl ibn Mubārak. Ed. Maulawi Abd-ur-Rahim. 3 vols. Calcutta: Asiatic

Society, 1873-1887.

Alberuni's India: An Account of the Religion, Philosophy, Literature, Geography, Chronology, Astronomy, Customs, Laws and Astrology of India, about A.D. 1030. Trans. and ed. E. C. Sachau. 2 vols. London: Trubner, 1888. Reprinted New Delhi: Asian Educational Services, 1993. 
Bhānucandraganicarita of Siddhicandra. Ed. Mohanlal Dalichand Desai. Ahmedabad-Calcutta: Sanchalaka-Singhi Jaina Granthamala, 1941.

Hìrasaubhāgya of Devavimalagani with his own gloss. Ed. Mahamahopadhyaya Pandit Sivadatta and Kashinath Pandurang Parab. Bombay: Tukaram Javaji, 1900.

Humāyūnnämah of Gulbadan Begum. In Three Memoirs of Homayun. Trans. and ed. Wheeler M. Thackston. Costa Mesa, CA: Mazda Publishers, 2009.

Jagadgurukāvya of Padmasāgara. In Vijayapraśastimahākāvya, ed. Hargovinddas and Becardas. Benares: Harakhchand Bhurabhai, 1911.

Jahāngīrnāmah. Ed. Muhammad Hashim. Tehran: Bunyad-i Farhang-i Iran, 1980.

Kalhaṇa's Rājataranginīi: A Chronicle of the Kings of Kaśmīr. Ed. M.A. Stein. Delhi: Banarsidass, 1979.

Krpārasakośa of Śānticandra. Ed. Muni Jinavijaya. Bhavnagar: Sri Jain Atmanand Sabha, 1917.

Mantrikarmacandravamśávalīprabandha of Jayasoma with the commentary of Gunavinaya. Ed. Acharya Muni Jinavijaya. Bombay: Bharatiya Vidya Bhavan, 1980.

Muntakhab al-Tavārìkh of 'Abd al-Qādir Badā'ūn̄i. Ed. Captain W. N. Lees and Munshi Ahmad Ali. Vol. 2. Calcutta: College Press, 1865.

Rājavamsavarnana. Jaipur: Sastra Bhandar of the Digambara Jain Bada Terapanthi Mandir, no, $17 \dot{1} 1$.

Rāstraudhavamśamahākāvya of Rudrakavi. Ed. Embar Krishnamacharya. Baroda: Central Library, 1917.

Rudrakavi's great poem of the dynasty of Rāstraudha, cantos 1-13 and 18-20. Trans. and ed. J. L. de Bruyne. Leiden: Brill, 1968.

Tārīkh-i Humāyūn of Bāyazīd Biyāt. In Three Memoirs of Homayun. Trans. and ed. Wheeler M. Thackston. Costa Mesa, CA: Mazda Publishers, 2009.

Tārīkh-i Shīr Shāhī of 'Abbās Khān Sarvānī. Trans. and ed. Brahmadeva Prasad Ambashthya. Patna: K. P. Jayaswal Research Institute, 1974.

Tazkirat al-vāghi 'āt of Jawhar Āftābchī. In Three Memoirs of Homayun, Trans. and ed. Wheeler M. Thackston. Costa Mesa, CA: Mazda Publishers, 2009.

Vijayapraśastimahākāvya of Hemavijaya with the commentary of Gunavijaya. Mumbai: Shri Jinashasan Aradhana Trust, 1988.

\section{Books and Articles}

Alam, Muzaffar. 'The Debate Within: A Sufi Critique of Religious Law, Tasawwuf and Politics in Mughal India'. South Asian History and Culture 2, no. 2 (2011): 138-59.

Alam, Muzaffar. 'Trade, State Policy and Regional Change: Aspects of Mughal-Uzbek Commercial Relations, c. 1550-1750'. Journal of the Economic and Social History of the Orient 37, no. 3 (1994): 202-27.

Ali, Daud. 'Indian Historical Writing, c. 600-1400'. In Oxford History of Historical Writing, 600-1400, ed. Sarah Foot and Chase F. Robinson. Oxford: Oxford University Press, forthcoming.

Andhare, Shridhar. 'Imperial Mughal Tolerance of Jainism and Jain Painting Activity in Gujarat'. In Arts of Mughal India: Studies in Honour of Robert Skelton, ed. R. Crill, S. Stronge, and A. Topsfield, 223-33. Ahmedabad: Mapin, 2004.

Bednar, Michael. 'Conquest and Resistance in Context: A Historiographical Reading of Sanskrit and Persian Battle Narratives'. Unpublished diss., The University of Texas at Austin, 2007.

Bell, Duncan. Victorian Visions of Global Order: Empire and International Relations in NineteenthCentury Political Thought. Cambridge: Cambridge University Press, 2007.

Bronner, Yigal. 'What is New and What is Navya: Sanskrit Poetics on the Eve of Colonialism'. Journal of Indian Philosophy 30 (2002): 441-62.

Busch, Allison. Poetry of Kings: The Classical Hindi Literature of Mughal India. Oxford: Oxford University Press, 2011.

Busch, Allison. 'Portrait of a Raja in a Badshah's World: Amrit Rai's Biography of Man Singh (1585)'. Journal of the Economic and Social History of the Orient (forthcoming).

Chatterjee, Kumkum. The Cultures of History in Early Modern India: Persianization and Mughal Culture in Bengal. New Delhi: Oxford University Press, 2009.

Chatterjee, Partha. 'Introduction'. In History in the Vernacular, ed. Raziuddin Aquil and Partha Chatterjee, 1-24. Delhi: Permanent Black, 2008.

Chattopadhyaya, Brajadulal. Representing the Other?: Sanskrit Sources and the Muslims (Eighth to Fourteenth Century). New Delhi: Manohar, 1998. 
Commissariat, M.S. A History of Gujarat, Including a Survey of Its Chief Architectural Monuments and Inscriptions, 3 vols, 1938-1980. Bombay and New York: Longmans, Green.

Commissariat, M.S. 'Imperial Mughal Farmans in Gujarat'. Journal of the University of Bombay 9, no. 1 (1940): $1-56$.

Cort, John. 'Genres of Jain History'. Journal of Indian Philosophy 23, no. 4 (1995): 469-506.

Cort, John. 'Who Is a King? Jain Narratives of Kingship in Medieval Western India'. In Open Boundaries: Jain Communities and Cultures in Indian History, ed. John E. Cort, 85-110. Albany: State University of New York Press, 1998.

Dale, Stephen Frederic. The Garden of the Eight Paradises: Bābur and the Culture of Empire in Central Asia, Afghanistan and India (1483-1530). Leiden: Brill, 2004.

Desai, Mohanlal Dalichand. 'Introduction'. In Bhānucandragaṇicarita, ed. Mohanlal Dalichand Desai, 1-91. Ahmedabad-Calcutta: Sanchalaka-Singhi Jaina Granthamala, 1941.

Deshpande, Prachi. Creative Pasts: History Memory and Identity in Western India, 1700-1960. New York: Columbia University Press, 2007.

Digby, Simon. 'Bāyazīd Beg Turkmān's Pilgrimage to Makka and Return to Gujarat: A Sixteenth Century Narrative'. Iran 42 (2004): 159-77.

Dundas, Paul. History, Scripture and Controversy in a Medieval Jain Sect, London: Routledge, 2007.

Dundas, Paul. 'Jain Perceptions of Islam in the Early Modern Period'. Indo-Iranian Journal 42, no. 1 (1999): 35-46.

Epigraphia Indica. Vol. 2. Delhi: Archaelogical Survey of India, 1891/92.

Ernst, Carl W. Eternal Garden: Mysticism, History, and Politics at a South Asian Sufi Center. Albany: State University of New York Press, 1992.

Faruqui, Munis. 'The Forgotten Prince: Mirza Hakim and the Formation of the Mughal Empire in India'. Journal of the Economic and Social History of the Orient 48, no. 4 (2005): 487-523.

Findly, Ellison B. 'Jahāngīr's Vow of Non-Violence'. Journal of the American Oriental Society 107, no. 2 (1987): 245-56.

Foltz, Richard. Mughal India and Central Asia. Karachi and New York: Oxford University Press, 1998.

Ganeri, Jonardon. The Lost Age of Reason: Philosophy in Early Modern India 1450-1700. Oxford: Oxford University Press, 2011.

Gopal, Surendra. 'The Jain Community and Akbar'. In Akbar and His Age, ed. Iqtidar Alam Khan, 160-7. New Delhi: Northern Book Centre, 1999.

Granoff, Phyllis. 'Authority and Innovation: A Study of the Use of Similes in the Biography of Hiravijaya to Provide Sanction for the Monk at Court'. Jinamanjari 1 (1990): 48-60.

Granoff, Phyllis. 'Biographical Writings Amongst the Śvetāmbara Jains in Northwestern India'. In According to Tradition: Hagiographical Writing in India, ed. Winand M. Callewaert and Rupert Snell, 131-58. Wiesbaden: Harrassowitz Verlag, 1994.

Granoff, Phyllis. 'Jinaprabhasūri and Jinadattasūri: Two Studies from the Śvetāmbara Jain Tradition'. In Speaking of Monks: Religious Biography in Asia, ed. Phyllis Granoff and Koichi Shinohara, 1-96. Oakville, ON: Mosaic Press, 1992.

Guha, Sumit. 'The Frontiers of Memory: What the Marathas Remembered of Vijayanagara'. Modern Asian Studies 43, no. 1 (2009): 269-88.

Guha, Sumit. 'Speaking Historically: The Changing Voices of Historical Narration in Western India, 1400-1900'. The American Historical Review 109, no. 4 (2004): 1084-103.

Hasan, Farhat. State and Locality in Mughal India: Power Relations in Western India, c. 1572-1730. Cambridge: Cambridge University Press, 2004.

Husain, Afzal. The Nobility under Akbar and Jahāngìr: A Study of Family Groups. New Delhi: Manohar, 1999.

Kansara, M.N. 'Introduction'. In Tilakamañjarīkathoddhārah, ed. M.N. Kansara, 1-30. Baroda: Oriental Institute, 1984.

Marshall, D.N. Mughals in India: A Bibliographical Survey. Vol. 1: Manuscripts. Bombay: Asia Publishing House, 1967.

Mayaram, Shail. Against History, Against State: Counterperspectives from the Margins. New York: Columbia University Press, 2003.

Mehta, Shirin. 'Akbar as Reflected in the Contemporary Jain Literature in Gujarat'. In Akbar and His Age, ed. Iqtidar Alam Khan, 223-30. New Delhi: Northern Book Centre, 1999.

Minkowski, Christopher. 'Advaita Vedānta in Early Modern History'. South Asian History and Culture 2, no. 2 (2011): 205-31. 
Minkowski, Christopher. 'On Sūryadāsa and the Invention of Bidirectional Poetry (vilomakāvya)'. Journal of the American Oriental Society 124, no. 2 (2004): 325-33.

New Catalogus Catalogorum: An Alphabetical Register of Sanskrit and Allied Works and Authors, ed. V. Raghavan, K. Kunjunni Raja, and T. Aufrecht. Madras: University of Madras, 1949-.

Nicholson, Andrew J. Unifying Hinduism: Philosophy and Identity in Indian Intellectual History. New York: Columbia University Press, 2010.

O'Hanlon, Rosalind. 'Speaking from Siva's temple: Banaras scholar households and the Brahman "ecumene" of Mughal India'. South Asian History and Culture 2, no. 2 (2011): 253-77.

Rosalind, O'Hanlon and David Washbrook. 'Religious Cultures in an Imperial Landscape'. South Asian History and Culture 2, no. 2 (2011): 133-7.

Pingree, David. From Astral Omens to Astrology: From Babylon to Bīkāner. Roma: Istituto Italiano Per L'Africa et l'Oriente, 1997.

Pollock, Sheldon. 'The Death of Sanskrit'. Comparative Study of Society and History 43, no. 2 (2001): 392-426.

Pollock, Sheldon. 'New Intellectuals in Seventeenth-Century India'. The Indian Economic and Social History Review 38, no. 1 (2001): 3-31.

Pollock, Sheldon. 'Pretextures of Time'. History and Theory 46 (2007): 364-81.

Pollock, Sheldon. 'Rāmāyaṇa and Political Imagination in India'. The Journal of Asian Studies 52, no. 2 (1993): 261-97.

Prabha, Chandra. Historical Mahākāvyas in Sanskrit, Eleventh to Fifteenth Century A.D. New Delhi: Meharchand Lachhmandas, 1976.

Prasad, Pushpa. 'Akbar and the Jains'. In Akbar and His India, ed. Irfan Habib, 97-108. Delhi: Oxford University Press, 1997.

Rao, Velcheru Narayana, David Dean Shulman, and Sanjay Subrahmanyam. Textures of Time: Writing History in South India, 1600-1800. New York: Other Press, 2003.

Ray, Sukumar and M.H.A. Beg. Bairam Khan. Karachi: Institute of Central and West Asian Studies, Faculty of Arts, University of Karachi, 1992.

Sarma, Sreeramula Rajeswara. 'A Bilingual Astrolabe from the Court of Jahangir'. Indian Historical Review 38, no.1 (2011): 77-117.

Sarma, Sreeramula Rajeswara. 'From Yāvanī to Samskrtam: Sanskrit Writings Inspired by Persian works'. Studies in the History of Indian Thought 14 (2002): 71-88.

Sarma, Sreeramula Rajeswara. 'Sanskrit Manuals for Learning Persian'. In Adab Shenasi, ed. A.D. Safavi, 1-12. Aligarh: Aligarh Muslim University, 1996.

Sarma, Sreeramula Rajeswara. 'Teach Yourself Persian the Sanskrit Way: A Survey of Sanskrit Manuals for Learning Persian, AD 1364-1764'. In Shri Hazari Mull Banthia Felicitation Volume. forthcoming.

Sastri, Hirananda. Ancient Vijñaptipatras. Baroda: Baroda State Press, 1942.

Sheikh, Samira. Forging a Region: Sultans, Traders, and Pilgrims in Gujarat, 1200-1500. Oxford: Oxford University Press, 2010.

Sheth, Chimanlal Bhailal. Jainism in Gujarat (A. D. 1100 to 1600). Bombay: Shree Vijaydevsur Sangh Gnan Samity, 1953.

Siddiqi, Iqtidar Husain. Shershah Sur and His Dynasty. Jaipur: Publication Scheme, 1995.

Slaje, Walter. Medieval Kashmir and the Science of History, Madden Lecture 2003-04. Austin: South Asia Institute, University of Texas, 2004.

Sreenivasan, Ramya. The Many Lives of a Rajput Queen: Heroic Pasts in India c. 1500-1900. Seattle: University of Washington Press, 2007.

Streusand, Douglas E. The Formation of the Mughal Empire. New York: Oxford University Press, 1989.

Taft, Frances H. 'Honor and Alliance: Reconsidering Mughal-Rajput Marriages'. In The Idea of Rajasthan: Explorations in Regional Identity, ed. Karine Schomer, Joan L Erdman, Deryck O. Lodrick, and Lloyd I Rudolph, 217-41. Vol. 2. New Delhi: Manohar, 1994.

Talbot, Cynthia, 'Inscribing the Other, Inscribing the Self: Hindu-Muslim Identities in Pre-Colonial India'. Comparative Studies in Society and History 37, no. 4 (1995): 692-722.

Talbot, Cynthia. 'The Mewar Court's Construction of History'. In The Kingdom of the Sun: Indian Court and Village Art from the Princely State of Mewar, ed. Joanna Williams, 12-33. San Francisco: Asian Art Museum, 2007.

Tawney, C.H., Trans. 'Preface'. In The Prabandhacintāmani or Wishing-stone of Narratives, v-xx. Calcutta: Asiatic Society, 1901. 
Thapar, Romila. Somanatha: The Many Voices of a History. London and New York: Verso, 2005.

Truschke, Audrey. 'Cosmopolitan Encounters: Sanskrit and Persian at the Mughal Court'. Unpublished diss., Columbia University, 2012.

Vidyavijayji, Muniraj. A Monk and a Monarch. Trans. Dolarrai R. Mankad. Ujjain: Deepchandji Banthia, 1944.

Vrat, Satya. Glimpses of Jaina Sanskrit Mahākāvyas. Jaipur: Raj Publishing House, 2003.

Wagoner, Phillip B. "Sultan among Hindu King": Dress, Titles, and the Islamicization of Hindu Culture at Vijayanagara'. The Journal of Asian Studies 55, no. 4 (1996): 851-80.

Zutshi, Chitralekha. 'Translating the Past: Rethinking Rajatarangini Narratives in Colonial India'. The Journal of Asian Studies 70, 1 (2011): 5-27. 